Szegedi Tudományegyetem, Fogorvostudományi Kar, Konzerváló- és Esztétikai Fogászati Tanszék, Szájüregi és Szisztémás Betegségek Kutatócsoport*

Szegedi Tudományegyetem, Fogorvostudományi Kar, Szájsebészeti Tanszék ${ }^{* *}$

Szegedi Tudományegyetem, Fogorvostudományi Kar, Parodontológiai Tanszék***

\title{
Dohányzás és pikkelysömör mint együttes rizikófaktor a fogágybetegségben
}

\author{
DR. GHEORGHITA DOROTTYA*, DR. ANTAL MÁRK ÁDÁM*, DR. NAGY KATALIN**, \\ DR. KERTÉSZ ANNAMÁRIA***, DR. BRAUNITZER GÁBOR* ${ }^{\star *}$
}

\begin{abstract}
Az irodalom a dohányzást és a pikkelysömört is a krónikus parodontitisre hajlamosító tényezők között tartja számon. Az is ismert, hogy a dohányzás a pikkelysömörben és a parodontitisben is állapotromlást idéz elő. Mindeddig azonban csak saját, korábbi tanulmányunk foglalkozott azzal, hogy a parodontitisre nézve milyen következményekkel jár, ha a pikkelysömörös beteg dohányzik is. Jelen munkánkban kibővített mintán ismételtük meg korábbi méréseinket. A vizsgálatban 82 beteg és 117 kontrollszemély vett részt. A parodontalis státusz jellemzéséhez teljes szájüregi vizsgálatot végeztünk. Az egyes kockázati tényezők fennállása esetén azt vizsgáltuk, hogy ezek mennyivel növelik meg a parodontitis súlyosabb stádiumainak kialakulási esélyét. A dohányzáshoz köthető kockázatnövekedés 1,32-szorosnak adódott $(p=0,465)$, a betegség fennállásával összefüggésbe hozható kockázatnövekedés pedig 1,85-szoros volt $(p=0,163)$. Ha a dohányzás a betegséggel együttesen állt fenn, a súlyos stádiumok kialakulásának esélye 6,22-ra növekedett $(p<0,001)$, ami többszöröse annak, mintha a kockázati tényezők egyszerűen kombinálódtak volna. Ez a kockázati tényezők szinergiájára utal.
\end{abstract}

Kulcsszó: parodontitis, psoriasis, dohányzás, immunológia

\section{Bevezetés}

Számos krónikus betegség megjelenése visszavezethető az alkoholfogyasztás, a mozgásszegény életmód, az egészségtelen táplálkozás és a dohányzás negatív hatásaira. A dohányzás jelenleg is globális közegészségügyi problémának számít [7]. Több populáció alapú epidemiológiai vizsgálat is kimutatta, hogy a fogágybetegség gyakrabban fordul elő dohányosoknál, mint nem dohányosoknál [4, 29]. A dohányfüst lokális irritáló hatása mellett bizonyított, hogy a dohányzás elősegíti a parodontopatogén baktériumok kolonizációját [15], befolyásolja a celluláris immunitást $[14,27,28]$ és hozzájárul bizonyos autoimmun és immunmediált kórfolyamatok kialakulásához $[8,17,18]$. Ezek alapján a dohányzás mint rizikótényező játszhat szerepet a parodontális gyulladás és a pikkelysömör létrejöttében. Az irodalom szerint ezek az állapotok egymásra is befolyással vannak. Az első olyan esettanulmány, amely a bőrtünetek fellángolásával párhuzamos parodontalis fellángolásokról számol be, Yamadától származik [30]. Az első esetkontroll vizsgálatot, amely komolyabban felveti a két állapot közötti lehetséges kapcsolatot, azonban csak tizennyolc évvel később, Preus és munkatársai publikálták [24]. Ezt követően két további hasonló munka is megerősítette a feltételezett összefüggést $[13,16]$.

Mind a pikkelysömör immunpatogenezise [26], mind a parodontális gyulladás kialakulása [22] összefüggésbe hozható a megváltozott T-limfocita-aktivitással. A parodontális gyulladás akkor válik erősen progreszszívvé, amikor a B-sejtes folyamatok kerülnek előtérbe, ezt pedig a $T_{H} h_{2}$ limfociták expanziója előzi meg. Ezen limfociták stimulálják a B-sejteket és interleukin szekrécióval (IL-4, IL-5 és IL-10) indukálják a humorális immunválaszt. Ugyancsak megemlítendő, hogy a $\mathrm{T}_{\mathrm{H} 1}$ sejtek szintén képesek a B-sejtek aktiválására INF-y szekréción keresztül, amely egy alternatív módja a B-sejt dominancia kialakulásának, különösen szupprimált T-sejt válasz esetén.

$T_{H} h_{1}$-stimuláció IL-6, IL-8, IL-12, IL-18, TNFa és INF-Y (autostimuláció) hatására következik be. Ezen markerek emelkedett szérumkoncentrációt mutatnak a krónikus plakk-típusú pikkelysömörben szenvedő pácienseknél is [2]. A fent említettek alapján nem túlzás azt feltételezni, hogy a pikkelysömör súlyosbíthatja a parodontális gyulladást, mivel a fokozott INF-y szekréció a $T_{H 2}$ dominancia (és ez által a $B$-sejtes válasz) irányába hat. Mivel a dohányzás befolyásolja az immunitást, elősegíti a parodontopatogén baktériumok kolonizációját, valamint lokálisan irritáló hatású, feltételezhetö, hogy trigger szerepet tölthet be a pikkelysömörös betegeknél a parodontális gyulladás kialakulásában. Ennek a feltételezésnek az ellenőrzésére kutatócsoportunk már korábban is végzett klinikai vizsgálómód- 
szerekre alapozott epidemiológiai vizsgálatot [1]. A parodontális gyulladás előfordulását és súlyosságát vizsgáltuk dohányzó és nemdohányzó pikkelysömörös betegek, valamint dohányzó és nemdohányzó kontrollcsoport összehasonlításával. Jelen tanulmányunkban a korábbi minta kibővítésével és a statisztikai elemzés pontosításával ugyanerre törekedtünk. Célunk volt, hogy meggyőződjünk arról, hogy korábbi eredményeink eltérő mintán is igazolhatók, és azt is fontosnak tartottuk, hogy a magyar nyelvű szaksajtóban egy újabb szempontból is felhívjuk a figyelmet a dohányzás komplex, a szájüregi egészséget változatos mechanizmusokon keresztül romboló hatására.

\section{Vizsgálati anyag és módszer}

A 82 fő pikkelysömörös páciens a Szegedi Tudományegyetem Bőrgyógyászati és Allergológiai Klinikája pikkelysömör ambulanciájának beteganyagából került kiválasztásra bőrgyógyász szakorvos diagnózisa alapján, a kontrollcsoport tagjait pedig (117 fő) kötelező tüdőszürésen megjelenő betegek közül, önkéntes alapon toboroztuk, a kor és a nem figyelembevételével. A szükséges esetszám kiszámítása G*Power 3.1.5. (University of Kiel, Germany) szoftverrel történt [10]. Az összesen 199 fős esetszámmal 0,9 feletti statisztikai erőt értünk el.

A vizsgálati csoportba kizárólag bőrgyógyász által diagnosztizált pikkelysömörös betegek kerültek (BNO-10 L40.0-L40.9). Kizáró tényezőként szisztémás betegségek (pl. cukorbetegség), extrém testsúly (BMI $\geq 30$ ), fokozott alkohol- vagy drogfogyasztás, ösztrogén-deficiencia, neutropeniát okozó betegségek és lokális vagy szisztémás gyulladásos kórállapotok szerepeltek. Elemszám-csökkenést eredményezett az, hogy néhány páciens nem felelt meg a vizsgálati kritériumoknak (főleg a fokozott alkoholfogyasztás következtében), néhányan nem vállalták az intraorális vizsgálatot, néhányan pedig elmulasztották megadni a dohányzással kapcsolatos adataikat. A végső, 82 fős betegszám ilyen módon alakult ki.

A demográfiai és dohányzási adatokat kérdőíven rögzítettük, az általános egészségi állapotra vonatkozó adatokat pedig a páciensek kartonjaiból nyertük ki. $A$ résztvevőket dohányzó és nemdohányzó csoportokba soroltuk.

A parodontális gyulladás pontos klinikai stádiumai jelenleg is vita tárgyát képezik, habár a betegség immunológiai/patológiai háttere jól dokumentált [22]. Talán a legelterjedtebb klasszifikáció a WHO által kifejlesztett

I. táblázat

A parodontalis gyulladás stádiumai a Fernandes-féle klinikai beosztás szerint és a stádiumoknak megfeleltethetô patológiai/kórélettani kép

\begin{tabular}{|c|c|}
\hline $\begin{array}{c}\text { Klinikai tünetek } \\
\text { (Fernandes és mtsai., 2009) }\end{array}$ & $\begin{array}{l}\text { Patológiai/Kórélettani stádiumok } \\
\text { (Ohlrich és mtsai., 2009) }\end{array}$ \\
\hline $\begin{array}{l}\text { 1. Nincsenek klinikai tünetek } \\
\text { - nincs tapadásvesztés (CAL), } \\
\text { sem szondázási ínyvérzés (BOP) }\end{array}$ & $\begin{array}{l}\text { (Nincs lézió } \\
\text { - Ohlrich és mtsai. által nem klasszifikált) }\end{array}$ \\
\hline $\begin{array}{l}\text { (Ínygyulladás } \\
\text { - Fernandes és mtsai. által nem klasszifikált) } \\
\text { (CPITN 1) }\end{array}$ & $\begin{array}{l}\text { 1. Kezdeti lézió } \\
\text { - legfeljebb } 4 \text { nappal plakk akkumulációt követően. } \\
\text { Polimorfonukleáris leukociták (PMN), kötőszövet-veszteség. } \\
\text { TNF-a felszabadulás a hízósejtekből, PMN migráció a gingivalis sulcusba, } \\
\text { de a fagocitózis sikertelen a bakteriális biofilm védő hatása miatt. } \\
\text { Lizoszómális enzimfelszabadulás a PMN sejtekből, } \\
\text { ami további szövetkárosodáshoz vezet. }\end{array}$ \\
\hline $\begin{array}{l}\text { 2. Korai parodontitis } \\
- \text { CAL } \geq 1 \mathrm{~mm}, \geq 2 \text { fognál } \\
\text { (CPITN } 2)\end{array}$ & $\begin{array}{l}\text { 2. Korai/stabil lézió } \\
\text {-7-21 nappal a plakk akkumulációt követően, klinikai tünetek megjelenése } \\
\text { kb. a 12. naptól. Makrofág és limfocita dominancia (CD4+ : CD8+2 : 1). } \\
\text { Perivascularis gyulladásos infiltrátum. Kiszélesedett epithelialis rések, } \\
\text { bakteriális termékek fokozott beszűrődése a gingiva szöveteibe. } \\
\text { A gyulladásos válasz kiterjedése. } \\
\text { Plakkeltávolítás esetén szöveti regeneráció még lehetséges. }\end{array}$ \\
\hline $\begin{array}{l}\text { 3. Elörehaladott parodontitis } \\
-3 \text { felszínen } \mathrm{CAL} \geq 4 \mathrm{~mm} \text {, } \\
\text { és legalább } 2 \text { felszínen a tasakmélység (PD) } \\
\geq 3 \mathrm{~mm} \\
\text { (CPITN 3) }\end{array}$ & $\begin{array}{l}\text { 3. Elörehaladott lézió } \\
\text { - dominánsan B sejt/plazmasejt-válasz. } \\
\text { Magas IL-1 és IL-6 szint: kötőszöveti veszteség és csontlebomlás. }\end{array}$ \\
\hline $\begin{array}{l}\text { 4. Súlyos parodontitis } \\
\text { - CAL } \geq 6 \mathrm{~mm} \geq 2 \text { fognál, } \\
\text { és } P D \geq 5 \mathrm{~mm} \geq 1 \text { felszínen } \\
\text { (CPITN 4) }\end{array}$ & $\begin{array}{l}\text { 4. Súlyos lézió } \\
\text { - nyilvánvaló tapadásveszteség. Magas IL-1, TNF-a és PGE2 szint, } \\
\text { ami a fibroblasztokat és a makrofágokat mátrix metalloproteázok } \\
\text { termelésére serkenti. A junkcionális epithel áthelyeződik apicalis irányba } \\
\text { (mélyül a periodontális tasak). Oligoclonalis } \mathrm{T}_{\mathrm{H} 2} \text { (CD4+) dominancia. }\end{array}$ \\
\hline
\end{tabular}


CPITN [3], amely meglehetősen tág kategóriákat definiál, így magában hordozza a túlminta-vételezés veszélyét. Ezen túlmenően a CPITN elsősorban nagyobb populációk rutinszerű és klinikai célú szürésére alkalmas. Mindezek figyelembevételével a Fernandes és munkatársai által javasolt, részletesebb osztályozást alkalmaztuk [11] (I. táblázat). A rendszerezéshez a következő paraméterek vizsgálatára volt szükség: a hiányzó fogak száma (a bölcsességfogak kivételével), Plakk-index (PI/Stillness-Löe Index), szondázási ínyvérzés (Bleeding on probing - BOP; szondázást követő 15 másodpercen belül a vérzés jelenlétének vagy hiányának vizsgálata), tasakmélység (Pocket Depth PD; milliméterben megadva), és tapadásveszteség (Clinical Attachment Level - CAL; az ínyszél helyzete a zománc-cement junkcióhoz képest).

Minden résztvevőnél teljes intraorális vizsgálatot végeztünk. A szondázási ínyvérzés, a tasakmélység és a tapadásveszteség értékeit a bölcsességfogak kivételével minden fog hat felszínén, Williams szondával (Hu-Friedy Manufacturing Co., Chicago, USA) mértük.

A vizsgálati- és a kontrollcsoport összehasonlítása a páciensek dohányzási státusza alapján történt (dohányzik/nem dohányzik). Ez az osztályozás némiképpen eltér a szokásostól, hiszen jobbára a leszokott státuszt is figyelembe szoktuk venni, azonban a konkrét mintában ez egy igen kis elemszámú (összehasonlításra alkalmatlan) alcsoportot eredményezett volna. Szintén változás, hogy míg korábbi vizsgálatunkban a Fernandes-féle klasszifikáció eredeti, 4 stádiumos elemzését végeztük el, ebben a vizsgálatban 2 fokozattal számoltunk (enyhe és súlyos). Az enyhe fokozatba az eredeti klasszifikáció 1-2, a súlyosba pedig 3-4 fokozatai tartoznak. Azon túl, hogy az új csoportosítással az egyes alcsoportok elemszáma - és ezáltal az analízis megbízhatósága - növelhető, ez a csoportosítás immunológiai szempontból is jól értelmezhető, ugyanis az 1-2 és 3-4 stádiumok között húzódik az a "határvonal”, ahol az immunfolyamatok a saját szövetek szempontjából is destruktívvá válnak (Id. I. táblázat). Az egyes stádiumok kialakulására regresszióanalízis segítségével esélyhányadosokat számoltunk. Az analitikai modellben a stádium mint végeredmény, a különböző faktorok pedig (pl. dohányos vagy nemdohányos, illetve pikkelysömörös vagy egészséges) faktorként szerepeltek. Az ösz- szefüggések elemzéséhez khi-négyzet próbát is alkalmaztunk. A statisztikai elemzéseket az SPSS 21.0 (SPSS, Inc., Chicago, USA) szoftverrel végeztük.

\section{Eredmények}

A minta leíró statisztikai jellemzőit a II. táblázatban közöljük. Amint az a táblázatból kitűnik, a nemek aránya a betegek körében közel azonos volt, míg a kontrollok között a női nem felülreprezentált volt, de ez az elemzések során nem okozott problémát, mivel a parodontitis súlyosságának szempontjából a nem sem a betegek $\left(x^{2}=2,481 ; p=0,161\right)$, sem a kontrollok $\left(x^{2}=2,831\right.$; $p=0,119)$ esetében nem bizonyult szignifikáns hatású tényezőnek. Maga a főcsoporthoz tartozás (beteg/kontroll) azonban erősen szignifikáns összefüggést mutatott a parodontalis gyulladás súlyosságával $\left(x^{2}=14,470\right.$; $\mathrm{p}<0,001)$.

A dohányzók aránya, korábbi vizsgálatainkhoz hasonlóan, most is a betegek körében volt magasabb, azonban az eltérés nem volt olyan mértékü, hogy ez torzíthatta volna az elemzést $\left(x^{2}=1,022 ; p=0,386\right)$.

Az egyes súlyossági fokozatok dohányzó és nemdohányzó alcsoportok szerinti alakulását az 1. ábra tartalmazza. Ebben a tekintetben figyelemre méltó, hogy miközben a dohányzó betegek (DB) körében az enyhe fokozat 11 esetben, a súlyos fokozat pedig 37 esetben fordult elő, a nemdohányzó kontrolloknál (NK) majdhogynem fordított arány volt megfigyelhető: 37 esetben enyhe fokozatú fogágyi érintettséget találtunk, súlyos fokozatot pedig 20 esetben. Bár az ábrán ezt külön nem emeltük ki, a kontrollok között 16 fő teljesen egészséges parodontalis állapotú személyt is találtunk, miközben a betegek között egészséges parodontiummal jellemezhető résztvevők egyáltalán nem fordultak elő.

A súlyos stádiumok kialakulásának esélyét (az enyhe stádiumokhoz viszonyítva) kiszámítottuk önállóan a dohányzásra, önállóan a pikkelysömörre, és mindkét kockázati tényező együttes fennállásának esetére is. A dohányzáshoz köthető kockázatnövekedés (a dohányzó és nemdohányzó kontrollok összehasonlításával) 1,32-szorosnak adódott $(p=0,465 ; \mathrm{Cl} 95 \%$ : $0,626-2,792$ ), a betegség fennállásával összefüggésbe hozható kockázatnövekedés pedig 1,85-szoros volt

II. táblázat

A vizsgálati csoportok jellemzése

\begin{tabular}{|l|c|c|}
\hline & Pikkelysömörös betegek $(n=82)$ & Kontroll csoport $(n=117)$ \\
\hline Kor (átlag \pm SD, év) & $54,1 \pm 13,5$ & $51,1 \pm 15,9$ \\
\hline dohányzó alcsoport & $53,3 \pm 13,8$ & $51,2 \pm 16,4$ \\
\hline nemdohányzó alcsoport & $54,7 \pm 12,9$ & $48,9 \pm 15,4$ \\
\hline Nemek aránya F : N (n (\%) : n (\%)) & $\mathbf{4 5 ( 5 5 \% ) ~ : ~ 3 7 ~ ( 4 5 \% ) ~}$ & $\mathbf{4 5}(\mathbf{3 8 , 5 \% )}: \mathbf{7 2}(\mathbf{6 1 , 5 \% )}$ \\
\hline dohányzó alcsoport & $31(64,6 \%): 17(35,4 \%)$ & $27(45,0 \%): 33(55,0 \%)$ \\
\hline nemdohányzó alcsoport & $14(41,2 \%): 20(58,8 \%)$ & $18(31,6 \%): 39(68,4 \%)$ \\
\hline Dohányzók (n (\%)) & $\mathbf{4 8 ( 5 8 , 5 \% )}$ & $\mathbf{6 0} \mathbf{( 5 1 , 3 \% )}$ \\
\hline
\end{tabular}




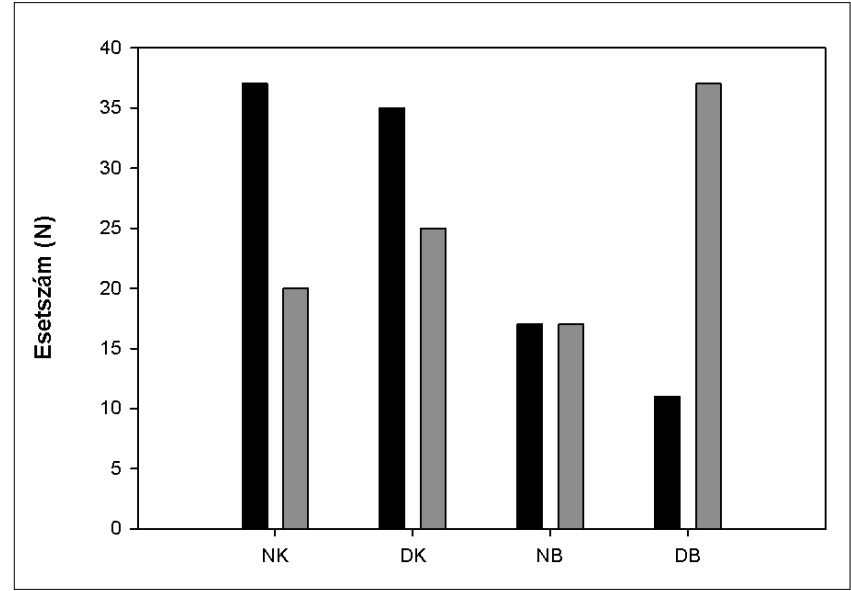

1. ábra: A parodontitis súlyossági stádiumainak alcsoportok szerinti megoszlása.

Fekete: enyhe stádiumok, szürke: súlyos stádiumok.

Figyeljük meg, hogy ebben a konkrét mintában

a nemdohányzó betegek között ugyanannyian voltak enyhe, mint súlyos fokozatokkal jellemezhetők, a dohányzás azonban

jól láthatóan a súlyos fokozatok túlsúlyát eredményezte!

$(p=0,163 ; \mathrm{Cl} 95 \%: 0,779-4,393)$. Ha azonban a dohányzás a betegséggel együttesen áltt fenn, a súlyos stádiumok kialakulásának esélye 6,22-re ugrott $(p<0,001$; Cl 95\%: 2,619-14,785).

A dohányzás a parodontalis gyulladás klinikai súlyosságával a pikkelysömörös betegeknél szignifikánsan összefüggött $\left(x^{2}=6,492 ; p<0,05\right)$, az egészséges kontrolloknál azonban nem $\left(X^{2}=0,535 ; p=0,569\right)$.

\section{Megbeszélés}

Korábbi eredményeinkhez hasonlóan a kibővített mintán is azt találtuk, hogy bár a dohányzás és a pikkelysömör külön-külön is megnövelik annak esélyét, hogy a parodontitis súlyos stádiumai alakulnak ki, a kockázat akkor válik csak igazán markánssá (és statisztikailag is szignifinkánssá), ha a két tényező együtt áll fenn. Ésszerü lenne az a következtetés, hogy ez a kockázatnövekedés csupán az egyéni rizikótényezők összeadódásának eredménye. Ez a feltételezés egyszerúen ellenőrizhető, mindössze az esélyhányadosok kombinálása szükséges hozzá. Két esélyhányados kombinálása hasonló mintanagyságok esetén úgy történik, hogy az egyes rizikófaktorok esélyhányadosainak logaritmusát egymással osztjuk ( $\left.\log O R_{1} / \log O R_{2}\right)$. Esetünkben a súlyos stádiumok pikkelysömörhöz köthető esélyhányadosát $(1,85)$ kombináltuk a dohányzás ugyanilyen vonatkozásban megadott esélyhányadosával $(1,32)$. Az eredmény 2,16 , ami jóval alatta marad a ténylegesen megfigyelt 6,22-os esélyhányadosnak. Ez arra enged következtetni, hogy a két kockázati tényező hatása nem pusztán összeadódik, közöttük valószínüleg szinergizmus lép fel.
Mindezekből arra következtetünk, hogy a dohányzás - bár önmagában nem növeli jelentősen a parodontitis súlyos fokozatainak esélyét - pikkelysömörben egyfajta permisszív tényezőként lép fel, ami a gyulladásos folyamatok destruktívba fordulásához vezet.

Továbbá, a dohányzás és a parodontális gyulladás súlyossága közötti összefüggés csak a vizsgálati csoportban mutatott szignifikanciát, ami szintén alátámasztja, hogy a dohányzás és a pikkelysömör együttesen idézi elő a megfigyelt hatást. Azonban a szignifikancia hiányát hiba lenne úgy értelmezni, mint annak bizonyítékát, hogy a dohányfüst önmagában nincs káros hatással a parodontiumra. Mára már evidenciának számít, de az irodalomban is számos alkalommal bizonyítást nyert, hogy ilyen fajta károsító hatás létezik (pl. Tonetti 1998), és arról sem szabad megfeledkeznünk, hogy - amint arra már korábbi vizsgálatunkban rámutattunk - amikor a betegség bármely fokozatának a kialakulását határozzuk meg az analízis kimeneteként (nem pedig fokozatonként elemeztünk), az összefüggés szignifikáns. Összegezve ez arra enged következtetni, hogy a dohányzás a pikkelysömör meglététől függetlenül szignifikánsan emeli annak esélyét, hogy a parodontitis kialakul, azonban ha a pikkelysömör mint alapbetegség is jelen van, a súlyosabb stádiumok válnak dominánssá.

Mivel korábban egyetlen tanulmány sem foglalkozott specifikusan azzal a kérdéssel, hogy milyen hatásai vannak a dohányzásnak a fogágybetegségre pikkelysömörben szenvedő betegeknél, és mi magunk is csak epidemiológiai jellegű, előkészítő vizsgálatokat végeztünk a későbbi immunológiai kutatásokat megalapozandó, a megfigyelések magyarázata meghaladja lehetőségeinket. Azonban elég ismerettel rendelkezünk a pikkelysömör és a parodontalis gyulladás patogeneziséről és a dohányzás kórélettani hatásairól ahhoz, hogy felállíthassunk egy hipotézist, amit az alábbiakban röviden vázolunk.

Ahogyan Ohlrich és munkatársai kifejtették, a legegyértelmübb különbség a parodontalis gyulladás korai és elörehaladottabb stádiumai között az, hogy az elörehaladottabb stádiumokban a gyulladásos választ nem a T-limfociták, hanem a B-limfociták uralják [22]. A fokozott és maladaptív B-sejtes/plazmasejtes válasz hatására végső soron bekövetkezik a parodontium szöveteinek destrukciója és a csontlebomlás. Hipotézisünk ebből kiindulva a T- és B-sejtes válaszok egyensúlyának eltolódására összpontosít. Jelen tanulmányban csak a feltételezett immunológiai háttérre fókuszálunk, miközben nyilvánvaló, hogy egyéb tényezők (így pl. dohányzás káros hatása a gingiva véráramlására) is hozzájárulnak a folyamat kimeneteléhez [19, 20].

Ismeretes, hogy pikkelysömörben olyan gyulladásos mediátorok vannak jelen, amelyek a B-sejtes válasz irányába történő eltolódásnak kedveznek [2]. Krónikus plakk-típusú pikkelysömörben az IL-6, IL-8, IL-12, IL-18, TNF- $\alpha$ és az INF-y szérumkoncentrációja emelkedett. Ezen mediátorok mindegyike B-sejt aktivá- 
ló $[6,9,12,25]$. A TNF- $\alpha$ szintén potens stimulálója a fibroblastoknak és a makrofágoknak, melyekből mátrix metalloproteázok szabadulnak fel [22]. Ezen hatások összessége a szöveti destrukció irányába mutat, és magyarázhatja a pikkelysömör és a súlyos parodontalis gyulladás között fennálló, már régen ismert kapcsolatot, minthogy a parodontalis gyulladás destruktívba fordulásának immunológiai szempontból legjellemzőbb lépése a B-sejtes válasz dominánssá válása. Ezzel már magyarázatát adnánk egy ismert jelenségnek, de hogyan magyarázhatjuk a dohányzás szinergista hatását?

Bár szintén csak hipotetikus magyarázat, rá kívánunk mutatni a toll-like receptorok, ezen belül is különösen a 4-es típus (TLR 4) lehetséges szerepére. A tolllike receptorok jellemzően immunsejteken fejeződnek ki, és az immunválaszok közvetítésében van szerepük. A $T_{H 1}$ limfociták felszínén expresszálódó TLR 4 bakteriális lipopoliszacharidokhoz kötődve aktiválja a sejtet, ami ennek hatására INF-y termelésébe kezd, utóbbi pedig potens B-sejt aktivátor [21]. Normális esetben ez része a gingivalis sulcus bakteriális kolonizációjára adott immunválasznak. Ha azonban a TLR 4 expressziója túlzott, a válasz aránytalan és maladaptív lehet. Pace és munkacsoportja rámutatott, hogy a cigarettafüst COPD -s betegek légúti epitheliumában a TLR 4 felszaporodásához vezetett, és - érvelésük szerint - éppen ez vezet oda, hogy a COPD-s betegek légútjaiban dominánsan $\mathrm{T}_{\mathrm{H} 1}$-szabályozott immunválasz figyelhető meg. Ugyanezen tanulmányukban számolnak be arról is, hogy a dohányzás fokozza az epithelium bakteriális lipopoliszacharidok iránti affinitását [23]. Témánk szempontjából nem jelentéktelen, hogy a TLR 4 felszaporodását pikkelysömörös bőrben is megfigyelték [5]. Bár nem tudjuk, hogy ezek a megfigyelések mennyire alkalmazhatók a parodontiumra, az már az előbbiekből is világos, hogy a TLR 4 felszaporodása egy lehetséges útja annak, ahogyan a pikkelysömör eleve B-domináns immunológiai környezetében a parodontalis gyulladás jellege T-sejtesből B-sejtesbe fordul. Az irodalom alapján tehát megalapozott lenne ebben az irányban immunológiai kutatásokat kezdeni.

\section{Konklúzió}

Jelen tanulmányunk eredményei egyfelől további alátámasztást adnak a pikkelysömör és a súlyos fogágybetegség között fennálló, már számos alkalommal leírt kapcsolatnak, másfelől rámutatnak, hogy a dohányzás a pikkelysömörös betegek esetében sokszorosára növeli a súlyos fogágybetegség egyébként is meglévő kockázatát.

Ennek üzenete a napi orvosgyakorlat számára az, hogy a dohányzás elhagyásának (illetve az ebben nyújtott segítségnek) fontosságát ebben a betegcsoportban nem lehet eléggé hangsúlyozni. Eredményeink szerint az esztétikai vonatkozásai miatt egyébként is súlyos pszichés terhet jelentő pikkelysömör dohányzás ese- tén jóval valószínúbben szövődik súlyos fokú fogágybetegséggel is, ami csak fokozza a pszichoszociális hatásokat (halitosis, fogvesztés stb.), miközben - a dohányzás elhagyásával - ezek a komplikációk megelőzhetők. Talán ennél is fontosabb, hogy a dohányzás elhagyása nélkül a fogágy állapotának javítására tett erőfeszítéseink az esetek nagy részében hiábavalónak fognak bizonyulni.

\section{Irodalom}

1. Antal M, Braunitzer G, Mattheos N, Gyulai R, Nagy K: Smoking as a permissive factor of periodontal disease in psoriasis. PloS one, 2014, 9(3), e92333.

2. Arican O, Aral M, Sasmaz S, Ciragil $P$ : Serum levels of TNF-alpha, IFN-gamma, IL-6, IL-8, IL-12, IL-17, and IL-18 in patients with active psoriasis and correlation with disease severity. Mediators of inflammation, 2005; 2005(5), 273-279.

3. BARMES D: CPITN-a WHO initiative. International dental journal, 1994; 44(5 Suppl 1), 523-525.

4. Beck JD, Koch GG, Rozier RG, Tudor GE: Prevalence and risk indicators for periodontal attachment loss in a population of older community-dwelling blacks and whites. Journal of periodontology, 1990; 61(8), 521-528.

5. Curry JL, Qin JZ, Bonish B, Carrick R, Bacon P, Panella J, et al: Innate immune-related receptors in normal and psoriatic skin. Archives of pathology \& laboratory medicine, 2003; 127(2), 178-186.

6. Durali D, de Goer de Herve MG, Giron-Michel J, Azzarone B, DelFRAISSY JF, TAOUFIK Y: In human B cells, IL-12 triggers a cascade of molecular events similar to Th1 commitment. Blood, 2003; 102(12), 4084-4089.

7. Edwards R: The problem of tobacco smoking. Bmj, 2004; 328(7433), 217-219.

8. Emre S, Metin A, Demirseren DD, Kilic S, Isikoglu S, Erel O: The relationship between oxidative stress, smoking and the clinical severity of psoriasis. Journal of the European Academy of Dermatology and Venereology: JEADV, 2013; 27(3), e370-375.

9. Falkoff RJ, Muraguchi A, Hong JX, Butler JL, Dinarello CA, FAUCI AS: The effects of interleukin 1 on human $B$ cell activation and proliferation. Journal of immunology, 1983; 131(2), 801-805.

10. Faul F, Erdfelder E, Lang AG, Buchner A: G*Power 3: a flexible statistical power analysis program for the social, behavioral, and biomedical sciences. Behavior research methods, 2007; 39(2), 175-191.

11. Fernandes JK, Wiegand RE, Salinas CF, Grossi SG, Sanders JJ, LOPES-VIRELLA MF, et al: Periodontal disease status in gullah african americans with type 2 diabetes living in South Carolina. Journal of periodontology, 2009; 80(7), 1062-1068.

12. Hirano T, Yasukawa K, Harada H, Taga T, Watanabe Y, Matsuda T, et al: Complementary DNA for a novel human interleukin (BSF-2) that induces B lymphocytes to produce immunoglobulin. Nature, 1986; 324(6092), 73-76.

13. KeLLER JJ, LIN HC: The effects of chronic periodontitis and its treatment on the subsequent risk of psoriasis. The British journal of dermatology, 2012; 167(6), 1338-1344.

14. Korn S, Wiewrodt R, Walz YC, Becker K, Mayer E, KrummenauER $F$, et al: Characterization of the interstitial lung and peripheral blood T cell receptor repertoire in cigarette smokers. American journal of respiratory cell and molecular biology, 2005; 32(2), 142-148.

15. Kubota M, Tanno-Nakanishi M, Yamada S, Okuda K, Ishihara K: Effect of smoking on subgingival microflora of patients with periodontitis in Japan. BMC oral health, 2011; 11, 1.

16. Lazaridou E, Tsikrikoni A, Fotiadou C, Kyrmanidou E, Vakirlis E, Giannopoulou C, et al: Association of chronic plaque psoriasis and severe periodontitis: a hospital based case-control study. 
Journal of the European Academy of Dermatology and Venereology: JEADV, 2013; 27(8), 967-972.

17. Masdottir $B$, Jonsson T, Manfredsdottir V, Vikingsson A, BrekKAN A, Valdimarsson H: Smoking, rheumatoid factor isotypes and severity of rheumatoid arthritis. Rheumatology, 2000; 39(11), 1202-1205.

18. Mathews JD, Whittingham S, Hooper BM, Mackay IR, Stenhouse NS: Association of autoantibodies with smoking, cardiovascular morbidity, and death in the Busselton population. Lancet, 1973; 2(7832), 754-758.

19. Mavropoulos A, Brodin P, Rosing CK, Aass AM, Aars H: Gingival blood flow in periodontitis patients before and after periodontal surgery assessed in smokers and non-smokers. Journal of periodontology, 2007; 78(9), 1774-1782.

20. Morozumi T, Kubota T, Sato T, Okuda K, Yoshe H: Smoking cessation increases gingival blood flow and gingival crevicular fluid. Journal of clinical periodontology, 2004; 31(4), 267-272.

21. Netea MG, Van der Meer JW, Sutmuller RP, Adema GJ, Kullberg BJ: From the Th1/Th2 paradigm towards a Toll-like receptor/Thelper bias. Antimicrobial agents and chemotherapy, 2005 49(10), 3991-3996.

22. Ohlrich EJ, Cullinan MP, Seymour GJ: The immunopathogenesis of periodontal disease. Australian dental journal, 2009; 54 Suppl 1, S2-10.

23. Pace E, Ferraro M, Siena L, Melis M, Montalbano AM, Johnson M, et al: Cigarette smoke increases Toll-like receptor 4 and modifies lipopolysaccharide-mediated responses in airway epithelial cells. Immunology, 2008; 124(3), 401-411.

24. Preus HR, Khanifam P, Kolltveit K, Mork C, Guermo P: Periodontitis in psoriasis patients: a blinded, case-controlled study. Acta odontologica Scandinavica, 2010; 68(3), 165-170.

25. Rieckmann P, D'Alessandro F, Nordan RP, Fauci AS, Kehrl JH IL-6 and tumor necrosis factor-alpha. Autocrine and paracrine cytokines involved in B cell function. Journal of immunology, 1991; 146(10), 3462-3468.

26. Schon MP, Boenncke WH: Psoriasis. The New England journal of medicine, 2005; 352(18), 1899-1912.

27. Sopori M: Effects of cigarette smoke on the immune system. Nature reviews Immunology, 2002; 2(5), 372-377.

28. Sullivan AK, Simonian PL, Falta MT, Mitchell JD, Cosgrove GP, Brown KK, et al: Oligoclonal CD4+ T cells in the lungs of patients with severe emphysema. American journal of respiratory and critical care medicine, 2005; 172(5), 590-596.

29. Tomar SL, Asma S: Smoking-attributable periodontitis in the United States: findings from NHANES III. National Health and Nutrition Examination Survey. Journal of periodontology, 2000; 71(5), 743-751.

30. Yamada J, Amar S, Petrungaro P: Psoriasis-associated periodontitis: a case report. Journal of periodontology, 1992; 63(10), 854857.

\section{Gheorghita D, Antal mÁ, Nagy K, Kertész A, Braunitzer G}

\section{Smoking and Psoriasis as Synergistic Risk Factors in Periodontal disease}

In the literature both smoking and psoriasis are discussed as predisposing factors for chronic periodontal disease. It is also known that smoking leads to deterioration in both psoriasis and periodontal disease. However, up to now, the only study to address the question what effect the co-occurrence of psoriasis and smoking has on the periodontal status of the individual, was a previous study of ours. In the present study, we repeated our measurements in an extended sample. 82 psoriatic patients and 117 controls participated, who all received a full-mouth examination so that their periodontal status could be determined. The analysis was aimed at finding out about to what extent the individual risk factors (i.e. smoking and psoriasis) increased the chance of the occurrence of the advanced stages of periodontal disease. The odds ratio for smoking was $1,32(p=0,465)$, and 1,85 for psoriasis $(p=0,163)$. In those patients who smoked, the odds ratio was $6,22(p<0,001)$, which is three times higher than the simple combination of odds. This suggests that the risk factors are in a synergistic relationship.

Key words: periodontitis, psoriasis, smoking, immunology 